\title{
Maatalousyrityksen kokonaisvaltainen johtaminen - Johto-hanke
}

\author{
Sari Morri ${ }^{1)}$, Matti Ryhänen ${ }^{2)}$, Ari Nopanen ${ }^{3)}$ ja Timo Pajula ${ }^{1)}$ \\ 1)ProAgria Etelä-Pohjanmaa, Huhtalantie 2,60220 Seinäjoki, etunimi.sukunimi@proagria.fi \\ ${ }^{2)}$ Seinäjoen ammattikorkeakoulu, SeAMK Ruoka, PL 412, 60101 Seinäjoki, \\ matti.ryhanen@seamk.fi \\ ${ }^{3)}$ ProAgria Keskusten liitto,Urheilutie6 D,01300Vantaa,ari.nopanen@proagria.fi
}

\section{TIIVISTELMÄ}

Maatalousyrittäjän tekemät päätökset vaikuttavat eripituisille ajanjaksoille. Maatalousyrittäjän operatiivisten päätöksien tueksi ProAgrialla on tarjolla runsaasti neuvontapalveluja ja niitä tukevia ohjelmistoja. Sen sijaan strategisiin päätöksiin ja strategiseen johtamiseen liittyvä tuki maatalousyrittäjille on vähäistä. On tärkeää kehittää maatalousyrittäjien strategista johtamisosaamista. Erityisesti on tarve kehittää maatalousyrittäjien kokonaisvaltaista johtamisosaamista, millä mahdollistetaan maatalousyritysten toimintojen ja tuotantoprosessien määrätietoinen johtaminen kokonaisuutena.

Maatalousyrittäjien kokonaisvaltaisen johtamisosaamisen kehittämistoimien lähtökohtana hyödynnetään tutkimustuloksia. Hankkeen tavoitteena on luotettavan tutkimustiedon pohjalta kehittää maatalousyrittäjien johtamisosaamista ja sparrata heitä laatimaan strategia ja viemään se käytännön toimiksi. Kokonaisvaltaisella johtamisella kannattavuutta maidontuotantoon -julkaisun tuloksia sovelletaan maatalousyrittäjien johtamistaitojen kehittämisessä. Lisäksi hyödynnetään ProAgrian asiantuntijoiden osaamista ja kokemusta, jonka he ovat saaneet toimiessaan asiakkaidensa kanssa.

Toimintaympäristön muutosten vuoksi johtamishaasteet maatalousyrityksissä ovat kasvaneet. Maatalousyrittäjien on siirryttävä käytännön toimien tekijöistä yritysjohtajiksi. Tällä hetkellä johtamisen merkitystä maatalousyrityksissä ei ole riittävästi ymmärretty. Maatalousyrittäjän on osattava johtaa itseään, muita henkilöitä ja maatalousyrityksen toimintaa. Tällä hankkeella vastataan yritystoimintaa kehittävien maatalousyrittäjien johtamisosaamistarpeisiin, jotta yritystoiminnan tuottavuutta ja kannattavuutta sekä henkilöiden hyvinvointia voidaan parantaa. Hankkeessa otetaan käyttöön uusimpia työkaluja ja toimintamalleja maatalousyrityksen kokonaisvaltaisen johtamisen tueksi. Pienryhmissä jaetaan uutta tutkimustietoa, sovelletaan testattuja käytännön kokemuksia sekä vertaillaan tuloksia ja kokemuksia toisten maatalousyrittäjien kanssa.

Maatalousyritysten koon kasvun myötä henkilöstöjohtamisen (HRM) ja yhteistyöverkostojen johtamisen tarve kasvaa. Maatalousyrityksissä henkilöjohtaminen lähtee hyvästä itsensä johtamisessa kuten oikeiden asioiden tekemisestä oikein ja myös ei-valinnoista. Hyvällä henkilöstöjohtamisella työvoima saadaan motivoitua ja sitoutettua työhönsä sekä tukemaan toimillaan maatalousyrityksen kehittämistä strategian mukaisesti.

Asiasanat: maatalousyrittäjä, johtaminen, kannattavuus

\section{Johdanto}

Perinteinen maataloustuotanto on pitkälti perustunut totuttuihin toimintatapoihin. Päivittäisten rutiinitöiden hoitaminen on koettu tärkeämmäksi kuin pitkän aikavälin yritystoiminnan kehittäminen, suunnittelu ja johtaminen. Ne on nähty tehtäviksi, joita ei ehditä toteuttaa arjen kiireessä. (vrt. Ryhänen ym. 2015). Perinteisesti itse tekeminen on ollut yleistä maatilayrityksissä, joissa yksi tai kaksi henkilöä on päätoimisesti työllistynyt (Pyykkönen ja Tiilikainen 2009). Monissa maatalousyrityksissä tuotantoprosesseja ja toimintoja on kehitetty kokonaisuudesta irrallaan (vrt. Sipiläinen, Ovaska \& Ryhänen 2012). Maatalousneuvonta on keskittynyt tuotantotoiminnan kehittämiseen, jolloin taloudellisen osaamisen ja johtamisen tuki on jäänyt vähäiseksi (vrt. Ryhänen \& Laitila 2014, Ryhänen ym. 2015, Karhinen 2019). 
Toimintaympäristön muutos on tuonut maatalousyrittäjälle paineen hakea uusia toimintatapoja ja ratkaisuja. Vaikka maatalousyrittäminen poikkeaa monilta osin teollisuus- ja liikeyritysten yritystoiminnasta, markkinaohjautuvuuden kasvun, tuotannon pääomavaltaistumisen ja kilpailun kovenemisen myötä maatalousyrityksiä on tarve johtaa strategisesti (vrt. mm. Ondersteijn ym. 2003, Olson 2004, Hegrenes 2005). Strateginen ajattelu saa maatalousyrittäjän pohtimaan tulevaisuutta ja näkemään sinne. Perinteisen toimintatavan kyseenalaistamalla ja uusia toimintatapoja hakemalla maatalousyrittäjä voi parantaa kilpailukykyä ja kannattavuutta. Strateginen suunnittelu antaa lähtökohdat strategiselle johtamiselle (vrt. Mintzberg 1991, Santalainen 2006).

Strategisella johtamisella maatalousyrittäjä vastaa toimintaympäristön muutoksiin. Maatalousyrittäjälle strateginen päätös voi olla esimerkiksi se, jatkaako hän yritystoimintaa perinteisesti eli itse tehden, hyödyntääkö hän erilaisia yhteistyömuotoja vai rakentaako hän laajoja yhteistyöverkostoja. Näillä päätöksillä maatalousyrittäjä voi vaikuttaa yritystoiminnan tuottavuuteen ja kannattavuuteen. Kokonaisvaltaisessa johtamisessa luodaan strategia ja organisoidaan yritystoiminta toteuttamaan sitä kilpailukyvyn ja kannattavuuden parantamiseksi. Tavoitteet ovat kärki, johon tähdätään. Strategia on keino tavoitteiden saavuttamisessa. Strateginen päätös kehittää maatalousyrittämistä syntyy monitahoisten tekijöiden yhteisvaikutuksen tuloksena, minkä ymmärtäminen vaatii tämän jäsentelyprosessin tuntemista (Hansson ja Ferguson 2011).

Strategian laatiminen ei takaa menestystä, mutta se parantaa menestymisedellytyksiä. Maatalousyrittäjä, jolta strategia puuttuu, kehittää yksittäisiä asioita kokonaisuudesta irrallaan. Se heikentää hänen asemaansa suhteessa maatalousyrittäjiin, jotka johtavat yritystään kokonaisuutena. Kaikkein valmeimpia suunnittelemaan strategista muutosta ovat maatalousyrittäjät, joille voiton tavoittelu ja yrityskoon kasvu ovat tärkeitä asioita. Maaseudulla elämistä arvostavat ovat valmeimpia jatkamaan tuotantoa ennallaan (vrt. Ferguson ja Hansson 2013).

Monet maatalousyrittäjät kokevat uudet toimintatavat vieraiksi. Osa maatalousyrittäjistä kokee yritystoiminnan osana itseään ja pitää neuvomista henkilökohtaisena kritiikkinä. Maatalousyrittäjät tarvitsevat tietoa, mistä apua saa, kun taloudelliset asiat ovat ajautumassa ongelmiin. Maatalousyrittäjiä autetaan parhaiten, kun heitä autetaan hahmottamaan kehittämistarpeita oma-aloitteisesti. Osa maatalousyrittäjistä ottaa epäonnistumisen henkilökohtaisesti, mikä aiheuttaa masennusta, toivottomuutta ja häpeää. Osa heistä vähättelee tai piilottelee epäonnistumista niin pitkään, että yritystoiminnan pelastamisessa ei enää voida auttaa (Ryhänen ja Närvä 2019).

Maatalousyrittäjät tarvitsevat lisää ymmärrystä liikkeenjohdosta ja yritystaloudesta, kykyä hyödyntää tutkimustuloksia ja halua tarttua uusiin mahdollisuuksiin. Johtamisen merkitystä maatalousyritysten menestymiseen ei olla vielä täysimääräisesti ymmärretty, sillä maatalousyrittäjien talousosaaminen ja johtamistaidot ovat olleet puutteellisia (Ryhänen ja Närvä 2019). Viime vuosien muutosten myötä johtamishaasteet ovat kasvaneet entisestään.

Tulevaisuuteen suuntaava maatalousyrittäjä johtaa yritystään kokonaisvaltaisesti, jolloin strateginen ja operatiivinen johtaminen muodostavat kokonaisuuden, jossa pitkän aikavälin tavoitteita toteutetaan kaikissa lyhyen aikavälin toimissa. Kokonaisvaltaisella johtamisella edistetään maatalousyrityksen tasapainoista kehittämistä ja luodaan edellytykset kannattavuuden parantamiselle. Tulevaisuudessa on vaikea kuvitella menestyvää maatalousyritystä, jota ei johdeta kokonaisvaltaisesti.

Maatalousyrittäjien liikkeenjohdon ja yritystalouden osaamisen saamiseksi riittävälle tasolle, tarvitaan uudenlaista koulutusta ja neuvontaa. Kokonaisvaltainen johtaminen, strateginen suunnittelu ja kokonaisuuden hallinta auttavat maatalousyrittäjiä kehittämään yritystoimintaa kestävältä pohjalta. Nykyisessä toimintaympäristössä maatalousyrittäjän on muututtava käytännön tuottajasta maatalousyrittäjäksi. Kasvavat maatalousyritykset tarvitsevat yhteistyötä ja verkostoja. Maatalousyrittäjän on osattava johtaa strategian mukaisesti yrityksensä toimintaa (vrt. Karhinen 2019). 
ProAgria Etelä-Pohjanmaan maitotilayrittäjistä koostuvan Maitotilavaliokunnan mukaan strategian kirkastamiselle ja päivitykselle on tarve. He toivoivat maatalousyrityksen johtamiseen työkaluja toimintavaihtoehtojen arviointiin ja eri prosessien kehittämiseen. Johtamisosaamisen kehittämiseksi kaivataan lisätietoa ja ymmärrystä talouden, tuottavuuden ja tehokkuuden tunnusluvuista. Kokonaisuuden hahmottamisessa sekä eri henkilöiden toimenkuvien ymmärtämisessä koettiin kehitettävää. He pitävät tärkeänä parhaiden käytänteiden jakamista toisten maatalousyrittäjien kanssa.

Maatalousyritysten koon kasvun myötä henkilöstöjohtamisen (HRM) ja yhteistyöverkostojen johtamisen merkitys kasvaa. Maatalousyrittäjien henkilöstöjohtaminen lähtee hyvästä itsensä johtamisessa $\mathrm{mm}$. oikeiden asioiden tekemisestä oikein ja ei-valinnoista. Maatalousyrittäjät toivovat toimintamalleja systemaattiseen päätöksen tekoon. Hyvällä henkilöstöjohtamisella työvoima on motivoitunut ja sitoutunut ja tukee näin maatalousyrityksen kehittämistä strategian mukaisesti.

Johto-kehittämishankkeen tavoitteet ovat seuraavat:

1. Kehittää tutkimustiedon pohjalta maatalousyrittäjien kokonaisvaltaista johtamisosaamista.

- Erityisesti tavoitteena on auttaa maatalousyrittäjiä kehittämään johtamisosaamistaan, millä mahdollistetaan maatalousyritysten toimintojen ja tuotantoprosessien määrätietoinen johtaminen kokonaisuutena.

2. Sparrata maatalousyrittäjiä laatimaan strategia ja viemään se käytännön toimiksi.

3. Tukea maatalousyrittäjiä toimimaan strategian mukaisesti.

4. Parantaa henkilöstöjohtamisen valmiuksia.

5. Hyödyntää tutkimustuloksia neuvonnan kehittämisessä.

\section{Aineisto ja menetelmät}

Johto-hankkeen tarvetta kartoitettiin ProAgria Etelä-Pohjanmaan maatalousyrittäjille tekemillä kartoituskeskusteluilla. Kehittämishankkeen aineisto koostuu tutkimustulosten soveltamisesta käytäntöön, kokonaisvaltaisen johtamisen mallin käytöstä ja benchmarking-aineistoista. Menetelmänä on pienryhmissä opiskelu ja tiedon jakaminen. Benchmarkingia tehdään maatalousyritysten välillä. Kokonaisvaltaisen johtamisen mallin pohjalta laaditaan maatalousyrityksille omat kokonaisvaltaisen johtamisen mallit, joita hyödynnetään maatalousyritysten johtamisessa. Palautteen avulla maatalousyrittäjät kehittävät johtamistaitojaan ja mallin hyödynnettävyyttä käytännön maatalousyrityksen johtamisessa.

Maatalousyrityksen kokonaisvaltaisen johtamisen mallin käytäntöön soveltamista on havainnollistettu kuvan 1 viitekehyksellä. Kokonaisvaltaisella johtamisella kannattavuutta maidontuotantoon -julkaisussa tuotetun soveltavan tutkimustiedon hyödyntäminen ja käytäntöön vienti (Kuvan 1 yläosa) antaa pohjan ProAgrian Johto-hankkeen kehitys- ja neuvontatyölle. Julkaisun tutkimuksissa tuotetun uuden tiedon pohjalta rakennettiin myös kokonaisvaltaisen johtamisen malli. Mallin rakentamisessa tärkeää oli sen soveltuvuus palvella käytännön maatalousyrittäjän tarpeita. Lisäksi tuotettiin sovellutusesmerkkejä, joita maatalousyrittäjä voi hyödyntää tarpeisiinsa (ks. Ryhänen ja Närvä 2019).

Tutkimustiedon hyödyntäminen maatalousyritysten johtamisessa (Kuvan 1 alaosa) on Johto-hankkeen keskeisin tehtävä. Maatalousyrityksen johtamista tarkastellaan hankkeessa laaja-alaisesti, mikä lähtee liikkeelle strategisesta ajattelusta, etenee tahtotilan muodostamiseen ja toimintamallin luomiseen, mikä lopulta päätyy käytännön toimiksi ja työtehtäviksi. Tahtotilan luonnin taustalla ovat toimintaympäristö-, resurssi- ja skenaarioanalyysit, joiden tuloksia hyödynnetään tahtotilan muodostamisessa. Maatalousyritykselle luodaan strategiset ja taloudelliset tavoitteet. Toimintamallin luonnin yhteydessä päätetään kehitysmittareista. Kehitysmittareita määritettäessä strategia konkretisoidaan niin, että sitä kyetään toteuttamaan määrätietoisesti operatiivisessa johtamisessa ja käytännön työtehtävien suorittamisessa. Tällöin käytännön työtehtävissä tehdään oikeita asioita oikein. 


\section{Uuden soveltavan tutkimustiedon tuottaminen ja vienti käytäntöön}

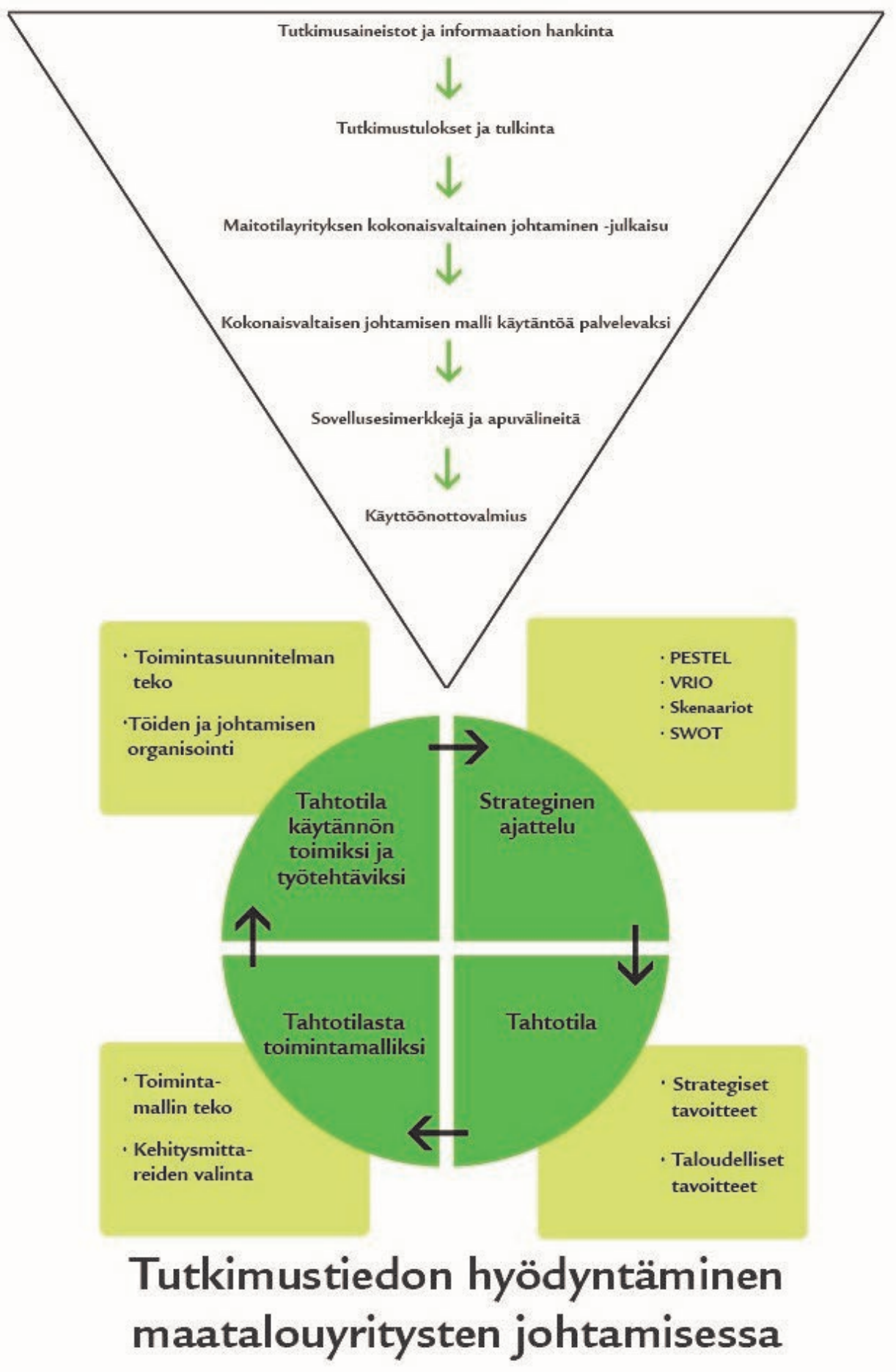

Kuva 1. Tutkimustiedon tuottaminen ja hyödyntäminen maatalousyritysten johtamisessa

\section{Toteutus}

Hankkeessa toimitaan pienryhmissä, joissa kussakin ryhmässä on 6-8 maatalousyritystä, yhteensä 3050 maatalousyrittäjää. Pienryhmissä jaetaan uutta tietoa, sovelletaan testattuja kokemuksia käytäntöön sekä vertaillaan uusia kokemuksia ja tuloksia toisten kanssa. Kussakin pienryhmässä voi olla eri tuotantosuuntien maatalousyrittäjiä. Jokainen pienryhmä toteutetaan saman ohjelmarungon mukaisesti, 
mutta sisältöä tarkennetaan ryhmäkohtaisesti. Kullakin pienryhmällä tapaamisia on kahdeksana päivänä ja tapaamiset pidetään noin 1,5 vuoden aikana. Pienryhmien välillä pidetään tarpeen ja mahdollisuuksien mukaan yhteisiä tapaamisia.

Pienryhmien tapaamiset ovat yhden tai kahden päivän tilaisuuksia. Aiheiden alustajina toimivat hankkeen asiantuntijat ja erikseen kutsutut luennoitsijat. Pienryhmätoiminnassa tavoitellaan sitä, että maatalousyrittäjät jakavat kokemuksiaan toisille avoimesti. Maatalousyrittäjien keskustelua tapaamisten välillä mahdollistetaan whatsapp-ryhmillä. Pienryhmätoiminta aloitetaan portaittain. Syksyllä 2019 aloitti kaksi ryhmää ja neljä ryhmää aloittaa vuosien 2020-2021 aikana.

Hankkeen toiminta on avointa ja kaikki hankealueen maatalousyrittäjät voivat osallistua hankkeeseen. Hankkeen vastuullinen toteuttaja on ProAgria Etelä-Pohjanmaa ry. Hanke toteutetaan yhteistyössä ProAgria Keskusten Liiton ja SeAMKin kanssa. ProAgria Etelä-Pohjanmaa tuo hankkeessa maatalousyrittäjien käyttöön uusinta tietoa maatalousyritysten strategisesta johtamisesta ja suunnittelusta yhteistyössä SeAMK:n ja ProAgria Keskusten Liiton kanssa. Hankkeen rahoittaa Etelä-Pohjanmaan ELY-keskus Manner-Suomen maaseudun kehittämisohjelmasta 2014-2020. Yksityisrahoitus koostuu pääosiltaan hankkeen yhteistyökumppaneina toimivien yritysten yksityisrahaosuudesta sekä maatalousyrittäjien pienryhmiin osallistujamaksuista. Hankeaika on 1.4.2019-31.12.2021.

\section{Odotetut tulokset}

Maatalousyrittäjien johtamisosaamisen lisäämisellä parannetaan maatalousyrityksen kilpailukykyä ja kannattavuutta. Maatalousyrittäjät johtavat yritystään kuin yritysjohtajat. Strategian avulla maatalousyrityksen toiminnalle saadaan selkeä suunta, minkä avulla päätöksenteko ja johtaminen selkeytyvät. Pitkäjänteisellä resurssien käytön suunnittelulla ja oikealla kohdentamisella vähennetään työ- ja pääomaresurssin hukkaa. Maatalousyrityksen verkostojen vahvistuminen lisää tuottavuutta ja tehostaa toimintaa. Operatiivista toimintaa kehitetään ja tehostetaan strategian mukaisesti. Maatalousyrittäjien jaksaminen ja hyvinvointi paranevat.

\section{Kirjallisuus}

Ferguson, R. \& Hansson, H. 2013. Expand or exit? Strategic decisions in milk production. Livestock Science 155: 415-423. https://doi.org/10.1016/j.livsci.2013.05.019

Hansson, H. \& Ferguson, R. 2011. Factors influencing the strategic decision to further develop dairy production - A study of farmers in central Sweden. Livestock Science 135: 110-123. https://doi.org/10.1016/j.livsci.2010.06.157

Hegrenes, A. 2005. The need for strategic planning. NJF Seminar 362. Strategic planning and management on farms. Nordic Association of Agricultural Scientists. NJF education and extension section. June15-17, 2005. Vantaa, Finland.

Karhinen, R. 2019. Uusi alku. Maatalous on myös tulevaisuuden elinkeino. Maa- ja metsätalousministeriön julkaisuja. 2019:3. Helsinki. Viitattu 28.12.2019. http://julkaisut.valtioneuvosto.fi/bitstream/handle/10024/161359/MMM_3_2019_Turvallista\%20ruokaa\%20Suomesta.pdf

Mintzberg, H. 1991. Strategic Thinking as "seeing". Teoksessa: J. Näsi (toim.) Arenas of Strategic Thinking. Helsinki: Foundation of Economic Education. S. 21-25.

Olson, K. 2004. Farm Management, Principles and Strategies. Ames, Iowa: Iowa state press.

Ondersteijn, C.J.M, Giesen, G.W.J \& Huirne, R.BM. 2003. Identification of farmer characteristics and farm strategies explaining changes in environmental management and economic performance on dairy farms. Agricultural Systems. 78:31-55. https://doi.org/10.1016/S0308-521X(03)00031-3 
Pyykkönen, P. \& Tiilikainen, S. 2009. Töiden organisointi Suomen maataloudessa. PTT:n raportteja 217.

Ryhänen, M. \& Laitila, E. 2014. Yhteistyö ja verkostosuhteet. Strateginen tarkastelu maidontuotantoon sovellettuna. Seinäjoen ammattikorkeakoulun julkaisusarja A. Tutkimuksia 19: 1-204.

https://doi.org/10.33354/smst.75283

Ryhänen, M. \& Närvä, M. (toim.) 2019. Kokonaisvaltaisella johtamisella kannattavuutta maidontuotantoon. Seinäjoen ammattikorkeakoulun julkaisusarja A. Tutkimuksia 31: 1-178.

https://doi.org/10.33354/smst.73223

Ryhänen, M., Närvä, M., Sipiläinen, T. \& Rajakorpi, J. 2015. Yhteisnavetan perustaminen ja johtaminen. Julkaisussa: T. Sipiläinen \& S. Lindberg 2015. (toim.) Maatilojen yhteistyö - esimerkkejä kotieläin ja kasvintuotannon yhteensovittamisesta. Helsingin yliopisto. Taloustieteen laitos. Selvityksiä 82:

57-90. [Viitattu 28.12.2019]. https://docplayer.fi/12804304-Timo-sipilainen-sara-lindberg-toim-maatilojen-yhteistyo-esimerkkeja-kotielainja-kasvintuotannon-yhteensovittamisesta.html

Santalainen, T. 2006. Strateginen ajattelu, 2. p. Helsinki: Talentum.

Sipiläinen, T., Ovaska, S. \& Ryhänen, M. 2012. Tuottavuus, tehokkuus ja taloudellinen tulos eteläpohjalaisilla maitotiloilla. MTT raportti 78: 9-41. Viitattu 28.12.2019. https://jukuri.luke.fi/bitstream/handle/10024/480641/mttraportti78.pdf?sequence=1\&isAllow 